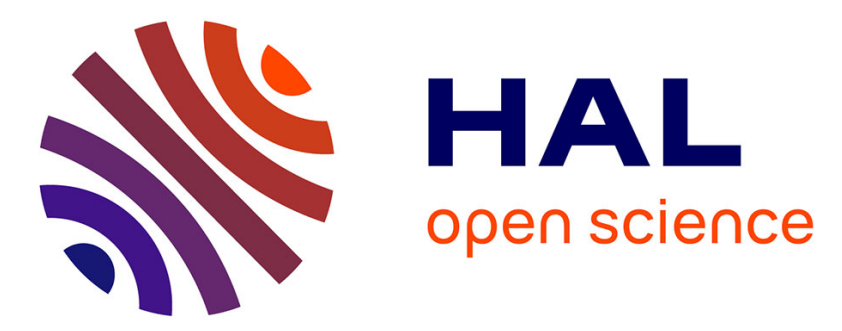

\title{
Challenges with Managing Disease Complexes during Application of Different Measures Against Foliar Diseases of Field Pea
}

Martin John Barbetti, Tanveer N., Ian Pritchard, Jay-Ram Lamichhane, Jean-Noël Aubertot, David Camilo Corrales Munoz, Ming Pei You

\section{To cite this version:}

Martin John Barbetti, Tanveer N., Ian Pritchard, Jay-Ram Lamichhane, Jean-Noël Aubertot, et al.. Challenges with Managing Disease Complexes during Application of Different Measures Against Foliar Diseases of Field Pea. Plant Disease, 2021, 105 (3), pp.616-627. 10.1094/PDIS-07-20-1470-RE . hal02937483

\section{HAL Id: hal-02937483 \\ https://hal.inrae.fr/hal-02937483}

Submitted on 14 Sep 2020

HAL is a multi-disciplinary open access archive for the deposit and dissemination of scientific research documents, whether they are published or not. The documents may come from teaching and research institutions in France or abroad, or from public or private research centers.
L'archive ouverte pluridisciplinaire HAL, est destinée au dépôt et à la diffusion de documents scientifiques de niveau recherche, publiés ou non, émanant des établissements d'enseignement et de recherche français ou étrangers, des laboratoires publics ou privés.

\section{(c)(1)}

Distributed under a Creative Commons Attribution| 4.0 International License 


\title{
Challenges with Managing Disease Complexes during Application of Different
}

\section{Measures Against Foliar Diseases of Field Pea}

\author{
Martin J. Barbetti ${ }^{1, \dagger}$, Tanveer N. Khan ${ }^{1}$, Ian Pritchard ${ }^{2}$, Jay Ram Lamichhane ${ }^{3}$, Jean-Noël Aubertot ${ }^{3}$, David Camilo \\ Corrales $^{3}$, Ming Pei You ${ }^{1}$ \\ ${ }^{1}$ School of Agriculture and Environment and UWA Institute of Agriculture, seeking The University of Western Australia, \\ WA, 6009, Australia \\ 2 Department of Primary Industry and Regional Development, Northam, WA 6401, Australia \\ ${ }^{3}$ INRAE, Université Fédérale de Toulouse, UMR AGIR, CS52627, F-31326 Castanet-Tolosan Cedex, France
}

†Corresponding author: M.J. Barbetti; E-mail: martin.barbett@@uwa.edu.au

\section{Abstract}

Studies were undertaken across five field locations in Western Australia to determine the relative changes in disease severity and subsequent field pea yield from up to four foliar pathogens associated with a field pea foliar disease complex (viz. Didymella, Phoma, Peronospora, Septoria), across four different pea varieties sown at three different times and at three different densities. Delaying sowing of field pea significantly $(P<0.05)$ reduced severity of Ascochyta blight (all five locations) and Septoria blight (1 location), increased severity of downy mildew (4 locations), but had no effect on seed yield. In relation to Ascochyta blight severity at 80 days after sowing, at all locations the early time of sowing had significantly $(P<0.05)$ more severe Ascochyta blight than the mid and late times of sowing. Increasing actual plant density from 20-25 plants $\mathrm{m}^{-2}$ to 58-78 plants $\mathrm{m}^{-2}$ significantly $(\mathrm{P}<0.05)$ increased the severity of the Ascochyta blight (4 locations) and downy mildew (1 location), and increased seed yield at four locations irrespective of sowing date and three locations irrespective of variety. Compared with varieties Dundale, Wirrega and Pennant, variety Alma showed significantly $(P<0.05)$ less severe Ascochyta blight (1 location), downy mildew (1 location) and Septoria blight (1 location). Grain yield was highest for the early time of sowing at three locations. Varieties Alma, Dundale and Wirrega significantly $(P<0.05)$ out yielded Pennant at four locations. The percentage of isolations of individual Ascochyta blight pathogens at 80 days after the first time of sowing varied greatly, with Didymella ranging $25-93 \%$ and Phoma from 6- $23 \%$ across the five field locations. This fluctuating nature of individual pathogen types and proportions within the Ascochyta blight complex, along with variation 
in occurrence of Peronospora and Septoria, highlights the challenges to understand and manage the complexities of cooccurring different foliar pathogens of field pea. While the search for more effective host resistance continues, there is a need for and opportunities from further exploring and exploiting cultural management approaches focussing on crop sequence diversification, intercropping, manipulating time of sowing and stand density, and application of improved seed sanitation and residue/inoculum management practices. We discuss the constraints and opportunities towards overcoming the challenges associated with managing foliar disease complexes in field pea.

Keywords. Pisum sativum, Ascochyta blight, Didymella pinodes, Phoma, Peronospora, Septoria, time of sowing, stand density

Field pea is affected by a range of foliar pathogens that can operate as a disease complex. In particular, this includes Ascochyta blight, that involves a complex of different pathogenic fungi, including Ascochyta pinodes (teleomorph: Didymella pinodes, also known as Mycosphaerella pinodes), Phoma pinodella (syn. Phoma medicaginis var. pinodella, formerly known as Ascochyta pinodella), and A. pisi, (Punithalingam and Holliday, 1972; Punithalingam and Gibson 1976; Hagedorn 1984; Onfroy et al. 1999; Davidson and Kimber 2007; McDonald and Peck 2009; Salam et al. 2011a,b,c,d,e; Khan et al. 2013). More recently there has been widespread Australian involvement of $P$. koolunga (Davidson et al. 2012; Tran et al. 2014a,b) where it has become a very important component of this complex (Davidson et al. 2009, 2011b, 2012; Tran et al. 2014a). The Ascochyta blight complex in Australia also includes, to a lesser extent, P. herbarum (Li et al. 2011), Boerema exigua var. exigua (Li et al. 2012), and P. glomerata (Tran et al. 2014c). However, the foliar disease complex on field pea can be wider than just two or more of the Ascochyta blight pathogens. For example, downy mildew (Peronospora viciae) and Septoria blight (Septoria pisi) can also affect field pea and frequently co-occur with Ascochyta blight pathogens.

Worldwide, historically, the focus for pea foliar disease has been primarily on $D$. pinodes, it being generally considered the most damaging fungal pathogen in the foliar disease complex (Moussart et al. 1998; Bretag et al. 2006; Tivoli and Banniza 2007; Le May et al. 2012; Khan et al. 2013). For example, D. pinodes is the dominant pathogen in the Ascochyta blight complex on the Canadian prairies (Gossen et al. 2011), and has historically has been considered as the primary pathogen of the Ascochyta blight complex across southern Australia (Bretag 1991; Khan et al. 2013). In France it is considered the most destructive and dominant field pea pathogen (Tivoli and Lemarchand 1992; Khan et al. 2013), despite A. pisi co-occurring in southern France (Tivoli and Banniza 2007). Cropping practices influence the ecological balance 
between pathogen species involved in the Ascochtya blight complex. In particular, $D$. pinodes can be favored and rendered dominant by management decisions in a given location or region. For example, in the mid-1960's in Canada, $D$. pinodes became the dominant species on field pea seed after the introduction of resistance to $A$. pisi (Tivoli and Banniza 2007). In Western Australia, the pathogen population associated with the Ascochyta blight has been dynamic across time and geographic location (Tran et al. 2014a), to the extent that $P$. koolunga can be even more virulent than $D$. pinodes and $P$. pinodella on stems and more virulent than D. pinodes on leaves of field pea (Tran et al. 2015).

Significant yield losses from Ascochyta blight are widely reported, and while they can be large, they vary depending upon environmental conditions and cropping systems. Examples of such variation include the following: France, where in 7 years out of 10, Ascochyta blight reduced yield by 20\% (Maufras 1997); in Canada, where average yield losses approximate 10\%, but with losses of $>50 \%$ in some situations (Xue et al. 1997); and in Australia, where yield losses $\geq 10 \%$ occurred annually (Bretag et al. 2006) but severe losses >50\% have been reported (Salam et al. 2011c; Khan et al. 2013). Even the extent of severe yield losses vary, ranging from $30-75 \%$ for Australia, France and Canada (Xue et al. 1997; Roger et al. 1999; Kaiser et al. 2000; Bretag and Ramsey 2001; McDonald and Peck, 2009). In Western Australia, Ascochyta blight is considered the overriding reason limiting the area sown to field pea (Salam et al. 2011a,b,c; Khan et al. 2013).

Unfortunately, Ascochyta blight remains extremely difficult to manage, mainly due to a paucity of effective host plant resistance, and a lack of cost-effective fungicide sprays, and even multiple fungicide spray applications throughout much of the growing season may still not provide effective management, as is the case in Western Australia (Salam et al. 2011c; Khan et al. 2013). In Australia, where the disease is particularly devastating (Salam and Galloway 2005), while there can be small differences in susceptibility between varieties, there remains a lack of effective resistance in commercial cultivars (Bretag et al. 2006; Khan et al. 2013; Tran et al. 2014b, 2015). This has meant that management of Ascochyta blight predominantly continues to rely on cultural options. Such cultural management options involve two main approaches. Firstly, minimising inoculum carry-over and survival of inoculum on crop residues and in soil, such as by crop rotation (Khan et al. 2013). Secondly, reducing infection of the crop from airborne inoculum arising from infested residues, such as by attempting to avoid the main ascospore showers (McDonald and Peck 2009; Khan et al. 2013). For example, in Australia, delaying sowing of field pea crops is widely utilized to ensure major ascospore showers precede field pea crop germination (Salam et al. 2011a,b,c), despite such an approach is not always an option in other countries, for example, in Canada due to the short season there. Even where delayed sowing it is an option for reducing Ascochyta blight, such an approach can incur unsustainable yield penalties from end-of-season moisture stress (Salam et al. 2011a,b,c; Khan et 
al. 2013). Other cultural management possibilities include lower planting densities to attempt to reduce both humidity (moisture) in the canopy and/or plant-to-plant spread of the disease.

Other foliar diseases outside of the Ascochyta blight complex can also be significant. First, downy mildew is also considered an important disease worldwide (Biddle 2001; Kraft 2001), including in Australia (Barbetti et al. 1989; Davidson et al. 2004, 2011a), significantly reducing seed yield (Biddle 2001; Davidson et al. 2004). While metalaxyl as a seed dressing can manage downy mildew (Biddle 2001), farmers are reluctant to do so because of perceived cost or the deleterious effect upon rhizobium inoculant (Davidson and Ramsey 2000). There is considerable variation within the $P$. viciae populations, both in Australia (Davidson et al. 2011) and elsewhere, such as in the United Kingdom (Taylor et al. 1989). Oospores of $P$. viciae readily survive for long periods in soil (van der Gaag et al. 1997) and pathogen elimination via a diversified crop sequence is challenging. Second, Septoria blight also occurs on field pea in some regions, particularly those with higher rainfall. However, in contrast to downy mildew, Septoria blight is generally considered a more minor foliar disease of local importance (Biddle 2001), for example, in Australia (Barbetti et al. 1989) and North America (Biddle 2001).

In Western Australia, delaying sowing is widely recommended as the primary means of reducing the level of Ascochyta blight (Salam et al. 2005, 2011a,b,c). However, the effects of delayed time of sowing on other foliar diseases outside the Ascochyta blight complex, and the possible effects of other management options, such as increasing sowing density or diversifying varieties, have not been determined. There is clearly a need to re-evaluate both the 'current recommended' and 'potential alternative' disease management practices. Hence, field studies were undertaken across five field locations in Western Australia, to determine the relative changes in disease severities of up to four foliar pathogens (genera Didymella, Phoma, Peronospora, Septoria), and consequent seed yield, from varying time of sowing and sowing density of four different field pea varieties.

\section{Materials and Methods}

General methods. Trials were all sown in the same year (1989) at five field locations in Western Australia; Avondale, East Beverley, Lake Grace, Merredin and Moora. Conventional field pea varieties used were Alma, Dundale, Pennant and Wirrega. Alma and Dundale have greenish-brown seed coats and are 'Dun' type. Wirrega and Pennant are white seeded and, as such, are preferred commercially. Each variety was sown using a cone seeder to three target plant densities of 25 , 
50, and 100 plants $\mathrm{m}^{-2}$, and with three sowing dates (early, mid and late (see location-specific details below). Each individual field plot size was $1.44 \times 25 \mathrm{~m}$.

Plants were assessed for Ascochyta blight severity on the stem and foliage using a 6 level ordinal scale where $S_{0}^{B}$ : symptomless; $S_{1}^{B}$ : trace of disease on base of plant; $S_{2}^{B}$ : disease affecting lower $25 \%$ stem length and foliage; $S_{3}^{B}$ : disease affecting lower $50 \%$ of stem length and foliage; $S_{4}^{B}$ : disease affecting lower $75 \%$ of stem and foliage; $S_{5}^{B}$ : disease affecting $100 \%$ stem and foliage. A total of 80 leaves and 80 stems showing Ascochyta blight symptoms were sampled at each disease assessment, examined directly under the microscope and then surface sterilized in $4 \% \mathrm{NaOCl}$ for 4 min and plated onto moist sterilized blotter paper in Petri dishes. Samples on moist blotter were examined at $24 \mathrm{~h}$ intervals under dissecting microscope for pathogen sporulation, then slides made and examined under an Olympus compound microscope to determine if Phoma or Didymella spores were present on each lesion. From this the percentage incidence of Phoma and Didymella associated with the disease symptoms calculated. In each case, identifications were confirmed by plating $1 \times 1 \mathrm{~mm}^{2}$ discs of leaf and stem diseased tissues onto potato dextrose agar containing $25 \mathrm{ppm}$ aureomycin hydrochloride. For Ascochyta blight, only data for 80 days after the first time of sowing are presented. Where downy mildew occurred, plants were assessed on a 11 level ordinal scale where $S_{0}^{D M}$ : nil disease; $S_{1}^{D M}: 1-10 \% ; S_{2}^{D M}: 11-20 \% ; S_{3}^{D M}: 21-30 \% ; S_{4}^{D M}$ : $31-40 \% ; S_{5}^{D M}: 41-50 \% S_{6}^{D M}: 51-60 \% ; S_{7}^{D M}: 1-70 \% ; S_{8}^{D M}: 71-80 \% ; S_{9}^{D M}: 81-90 \% ; S_{10}^{D M}: 91-100 \%$ of diseased leaf area. Septoria blight was assessed on a six level ordinal scale, where $S_{0}^{S}$ : nil disease; $S_{2}^{S}: 1-20 \% ; S_{3}^{S}$ : $21-40 \% ; S_{4}^{S}$ : $41-60 \% ; S_{5}^{S}$ : $61-80 \% ; S_{5}^{S}:>80 \%$ of leaf surface area was diseased. All disease ordinal disease scores were transformed into percentage disease indices $(\% \mathrm{DI})$ based on McKinney $(1923)$ where $\% \mathrm{DI}=($ sum of all numerical grades) $\times 100 \div$ (total number of plants scored $\mathrm{x}$ maximum rating score). These data for downy mildew and Septoria are presented across different assessment times (see details below). For each location, disease severity assessments were undertaken at multiple times at a range of dates across the season that allowed plants from each sowing time to be rated for disease at 80 days postsowing; i.e., the actual dates representative of 80 days after sowing for each time of sowing (see details below for each location).

Plant density measurements were made on all field plots 3 weeks after germination by counting the numbers of seedlings in each of 10 random quadrats, each $0.5 \times 0.5 \mathrm{~m}$, per plot. Sown and actual seedling density data is provided in Fig. 1. Grain yield was assessed by fully mechanically harvesting all plots and recording seed mass per plot that was then converted to $\mathrm{kg} \mathrm{ha}^{-1}$. 
Location-specific details and experimental factors. At Avondale, soil type was a red-brown sandy loam to clay loam over red brown to dark brown clay at $18 \mathrm{~cm}$. Sowing dates were: Early, June 9; Mid, June 20; and Late, June 30. Approximately $95 \mathrm{~kg} \mathrm{ha}^{-1}$ plain superphosphate fertilizer was drilled with seed. Mean monthly rainfall May to September inclusive were $46.9,62.7,69.9,52.6,35.5 \mathrm{~mm}$, respectively, while mean monthly maximum/minimum temperature were $21.3 / 7.8,17.2 / 5.9,16.0 / 5.1 .18 .0 / 5.1,20.7 / 5.8^{\circ} \mathrm{C}$, respectively. All times of sowing were assessed for diseases on August 28, September 9, 19 and October 13. The first three times of assessment represent the 80 days from sowing assessment for the first, second and third times of sowing respectively. At East Beverley, soil showed a surface A horizon of grey brown sand over a pale clayey sand $\left[\mathrm{pH}\left(\mathrm{H}_{2} \mathrm{O}\right) 5.5-6.5\right]$ overlying a sandy clay subsoil $\left[\mathrm{pH}\left(\mathrm{H}_{2} \mathrm{O}\right) 6.6-7.0\right]$ at a depth of 20-30 cm. Sowing dates were: Early, May 25, Mid, June 9, and Late, July 19. Approximately $100 \mathrm{~kg} \mathrm{ha}^{-1}$ plain superphosphate fertilizer was drilled with seed. Mean monthly rainfall May to September inclusive were 46.7, 66.6, 63.3, 47.6, $32.1 \mathrm{~mm}$, respectively, while mean monthly maximum/minimum temperature were $21.3 / 7.8,17.2 / 5.9,16.0 / 5.1 .18 .0 / 5.1,20.7 / 5.8^{\circ} \mathrm{C}$, respectively (Avondale being the closest location with available temperature data). All times of sowing were assessed for diseases on August 14, 28, September 8 and October 13. The first three dates of assessment represent the 80 days from sowing assessment for the first, second and third times of sowing respectively. At Lake Grace, soil type was a brown sandy loam 0-5 cm over clay. Sowing dates were: Early, May 26, Mid, June 22, and Late, July 17. Approximately $100 \mathrm{~kg} \mathrm{ha}^{-1}$ plain superphosphate fertilizer was drilled with seed. Mean monthly rainfall May to September inclusive were 41.7, 48.6, 47.7, 44.9, $32.8 \mathrm{~mm}$, respectively, while mean monthly maximum/minimum temperature were 20.8/7.5, 17.7/5.6, 16.5/4.6, 17.6/4.7, 20.4/5.9 ${ }^{\circ} \mathrm{C}$, respectively. All times of sowing were assessed for diseases on August 17, 31 and September 11. These three dates of assessment represent the 80 days from sowing assessment for the first, second and third times of sowing respectively. At Merredin, soil type was a reddish brown sandy clay loam $\left[\mathrm{pH}\left(\mathrm{CaCl}_{2}\right)\right.$ 6.0] over yellowish red heavy clay [pH 7.8] at 30cm. Early, May 3; Mid, May 19; and Late, June 2. Approximately $100 \mathrm{~kg} \mathrm{ha}^{-1}$ plain superphosphate fertilizer was drilled with seed. Mean monthly rainfall May to September inclusive were 40.0, 48.7, 50.2, 39.3, $25.5 \mathrm{~mm}$, respectively, while mean monthly maximum/minimum temperature were 19.9/8.9, 15.8/6.7, 15.0/5.5,17.4/5.6, 21.4/6.7 ${ }^{\circ} \mathrm{C}$, respectively. All times of sowing were assessed for diseases on July 24, August 7, 22 and September 5. The first three dates of assessment represent the 80 days from sowing assessment for the first, second and third times of sowing respectively. At Moora, soil type was a heavy brown sandy loam $\left[\mathrm{pH}\left(\mathrm{H}_{2} \mathrm{O}\right) 5.95\right]$ and with clay at $40 \mathrm{~cm}$. Sowing dates were: Early, May 26; Mid, June 16; and Late, June 30. Approximately $130 \mathrm{~kg} \mathrm{ha}^{-1}$ plain superphosphate fertilizer was drilled with seeds. Mean monthly rainfall May to September inclusive were 59.8, 88.3, 87.8, 68.7, $43.8 \mathrm{~mm}$, respectively, while 
mean monthly maximum/minimum temperature were $22.5 / 10.6,18.8 / 8.4,17.6 / 7.3,18.3 / 7.1,20.5 / 7.6{ }^{\circ} \mathrm{C}$, respectively. All times of sowing were assessed for diseases on August 15, September 4 and 18. These dates represent 80 days from sowing assessment for the first, second and third times of sowing respectively.

Experimental design and statistical analyses. A split plot design was used with three replicates and a plot size of $25 \mathrm{~m} \times 1.44 \mathrm{~m}$. There were five separate field locations and all experiments were done in the one year (1989). Plots were blocked into times of sowing, with varieties and seeding rates being completely randomised within time of sowing blocks. One and two way ANOVAs were conducted using GenStat (VSN International, 2019). Fisher's least significant differences (LSDs) were used to separate significant differences between treatments $(P \leq 0.05)$.

\section{Results}

Results overview. Only data for significant effects of time of sowing, sowing density and cultivar on severity of Ascochyta blight (Fig. 2), downy mildew (Fig. 3), Septoria blight (Fig. 4), and yield (Fig. 5) are provided. Delaying sowing of field pea significantly $(\mathrm{P}<0.05)$ reduced severity of Ascochyta blight (all five locations; Fig. 2) and Septoria blight $(1$ location; Fig. 4), increased severity of downy mildew (4 locations; Fig. 3); but had no effect on seed yield (Fig. 5). In relation to Ascochyta blight severity at 80 days after sowing, at all locations the early time of sowing had more severe Ascochyta blight than the mid and late times of sowing (Fig. 2).). Increased sowing density (actual plant density from 20-25 plants $\mathrm{m}^{-2}$ to 58-78 plants $\mathrm{m}^{-2}$; Fig. 1) significantly $(\mathrm{P}<0.05)$ increased Ascochyta blight (4 locations; Fig. 2$)$ and downy mildew $(1$ location; Fig. 3); and increased seed yield at four locations, the latter irrespective of sowing date or variety (Fig. 5) (with the exception of Dundale at Avondale and Merredin locations that showed no response to increasing plant densities). However, increasing the target plant density from 36-50 and 58-78 plants $\mathrm{m}^{-2}$ (Fig. 1) had no effect on seed yield (Fig. 5). Compared with varieties Dundale, Wirrega and Pennant, variety Alma showed significantly $(P<0.05)$ less severe Ascochyta (1 location), downy mildew (1 location) and Septoria blight (1 location). Grain yield was highest for the early time of sowing at Lake Grace, Moora and Avondale (Fig. 5). At Avondale and East Beverley, delaying to the late time of sowing had no significant effect on grain yield. However, at both Lake Grace and East Beverley, the mid time of sowing yielded significantly $(P<0.05)$ less than the early and late times of sowing. Varieties Alma, Dundale and Wirrega were the highest yielding varieties at four locations, with Pennant yielding significantly $(\mathrm{P}<0.05)$ less than these other three varieties $($ Fig. 5). The percentage of isolations of individual Ascochyta blight pathogens varied greatly, and at 80 days after first time of 
sowing showed Didymella from 25-93\% and Phoma from 6- 23\% across the five field locations. There was a predominance of Didymella by a 3.5 to 16 fold across the Avondale, East Beverley, Merredin and Moora locations, but $<1$ fold predominance of Didymella at Lake Grace (Table 1).

Location-specific results - Avondale. For Ascochyta blight, at 80 days after sowing, there were significant effects of time of sowing $(P<0.001)$ with the early time of sowing showing more severe Ascochyta blight $(P<0.01)$ than the mid and late times of sowing (Fig. 2). There were no effects of variety but there was a significant effect $(P<0.01)$ of sowing density where Ascochyta blight was more severe $(P<0.05)$ at a sowing density of 100 plants $\mathrm{m}^{-2}$ compared to 25 plants $\mathrm{m}^{-2}$ (Fig. 2). By August 28, there was a significant effect of time of sowing $(P<0.001)$, where early time of sowing had more severe Ascochyta blight $(P<0.05)$ than the mid time of sowing and this in turn had more severe disease $(P<0.05)$ than the late time of sowing. By September 8 , there was a significant effect of time of sowing $(P<0.001)$, where the early time of sowing had more severe Ascochyta blight $(P<0.05)$ than the mid and late times of sowing. By September 19 , the early time of sowing had more severe Ascochyta blight $(P<0.05)$ than the mid time of sowing and this in turn had more severe disease $(P<0.05)$ than the late time of sowing. By October 13 , there was a significant effect of time of sowing $(P<0.001)$, where the early time of sowing had more severe Ascochyta blight $(P<0.05)$ than the mid time of sowing and this in turn had more severe disease than the late time of sowing. There was a significant effect $(P<0.05)$ of sowing density on Ascochyta blight where disease was more severe $(P<0.05)$ at a sowing density of 100 plants $\mathrm{m}^{-2}$ compared to 25 plants $\mathrm{m}^{-2}$. There was also a significant $(P<0.05)$ interaction of time of sowing with sowing density. At 80 days after first time of sowing, direct examination and plating Ascochyta blight lesions on leaves and stems onto potato dextrose agar indicated that Didymella had an excellent association with lesions (84\%) while Phoma a much lower association (23\%) for this same range of lesions (Table 1).

For downy mildew, there was a rapid decrease in severity over the three assessments from August 28 to September 19. Downy mildew was more severe $(P<0.05)$ with delayed time of sowing at both August 28 and September 8 , but not at September 19 (Fig. 3).

For Septoria blight, by August 28, there were significant effects of time of sowing, variety and sowing density (all $P<0.001)$ and a significant interaction $(P<0.05)$ of time of sowing with sowing density in relation to its severity. Early and mid-times of sowing had more severe Septoria blight $(P<0.05)$, compared to the late time of sowing. Alma and Dundale had more severe Septoria blight $(P<0.05)$ than Pennant and Wirrega. Septoria blight was more severe $(P<0.05)$ at a sowing density of 100 plants $\mathrm{m}^{-2}$ compared with 50 plants $\mathrm{m}^{-2}$ which in turn had more severe disease than at 25 plants $\mathrm{m}^{-2}$. By September 8, there were significant effects of time of sowing $(P<0.01)$, variety $(P<0.001)$ and sowing density $(P<0.001)$. 
The early time of sowing had more severe Septoria blight $(P<0.05)$ compared to the mid and late times of sowing. Alma had more severe Septoria blight $(P<0.05)$ than Pennant and Wirrega, while Dundale had more disease $(P<0.05)$ than Pennant. Septoria blight was more severe $(P<0.05)$ at a sowing density of 100 plants $\mathrm{m}^{-2}$ compared to 50 plants $\mathrm{m}^{-2}$, which in turn had more severe disease $(P<0.05)$ than at 25 plants $\mathrm{m}^{-2}$ (Fig. 4).

Location-specific results - East Beverley. For Ascochyta blight, by 80 days after sowing, disease levels were generally low and the early time of sowing had more severe Ascochyta blight than the mid and late times of sowing (Fig. 2). Ascochyta blight was more severe $(P<0.05)$ both in Alma compared to Pennant and Wirrega, and at sowing density 100 plants $\mathrm{m}^{-2}$ compared to 25 plants $\mathrm{m}^{-2}$ (Fig. 2). There was a significant interaction of time of sowing with both variety and with sowing density (both $\mathrm{P}<0.01)$. By August 14 , there were significant effects of time of sowing $(P<0.001)$, variety $(P<0.05)$ and sowing density $(P<0.01)$ and significant interactions between time of sowing with both variety $(P<0.01)$ and with sowing density $(P<0.001)$ in relation to severity of Ascochyta blight. The early time of sowing had more severe Ascochyta blight $(\mathrm{P}<0.05)$ compared to the mid and late times of sowing. Alma and Dundale had more severe Ascochyta blight $(P<0.05)$ than Pennant and Wirrega. Ascochyta blight was more severe $(P<0.05)$ at 100 plants $\mathrm{m}^{-2}$ compared to 50 and 25 plants $\mathrm{m}^{-2}$. By August 28, there were significant effects of time of sowing $(P<0.001)$, variety $(P<0.05)$ and sowing density $(P<0.01)$ and significant interactions between time of sowing with both variety $(P<0.01)$ and with sowing density $(P<0.001)$ in relation to severity of Ascochyta blight. The early sowing had more severe Ascochyta blight $(P<0.05)$ compared to the mid and late times of sowing. Alma and Dundale had more severe Ascochyta blight $(P<0.05)$ than Pennant and Wirrega, and Ascochyta blight was more severe $(\mathrm{P}<0.05)$ at 100 and 50 plants $\mathrm{m}^{-2}$ compared to 25 plants $\mathrm{m}^{-2}$. By September 8, there were significant effects of time of sowing $(P<0.001)$, variety $(P<0.01)$ and sowing density $(P<0.001)$ and significant interactions between time of sowing with both variety $(P<0.01)$ and with sowing density $(P<0.001)$ in relation to severity of Ascochyta blight. The early sowing had more severe Ascochyta blight $(P<0.05)$ compared to the mid and late times of sowing. Alma and Dundale had more severe Ascochyta blight $(P<0.05)$ than Pennant and Wirrega. Ascochyta blight was more severe $(P<0.05)$ at a sowing density of 100 plants $\mathrm{m}^{-2}$ compared to 50 or 25 plants $\mathrm{m}^{-2}$. By October 13 , there were significant effects of time of sowing $(P<0.001)$ and sowing density $(P<0.01)$ and a significant interaction between time of sowing with seeding density $(P<0.05)$ in relation to severity of Ascochyta blight. The mid sowing had more severe Ascochyta blight $(P<0.05)$ compared to the early sowing, which in turn had more severe disease $(P<0.05)$ than the late sowing. Ascochyta blight was more severe $(P<0.05)$ at a sowing density of 100 plants $\mathrm{m}^{-2}$ compared to 25 plants $\mathrm{m}^{-2}$. At 80 days after first time of sowing, direct examination and plating Ascochyta blight lesions on leaves and stems onto potato 
dextrose agar indicated that Didymella had excellent association (98\%) with lesions while Phoma had poor association (6\%) with these lesions (Table 1).

For downy mildew for assessments made at August 14 and 28 , severity was greater $(P<0.05)$ in the mid and late times of sowing compared with the early time of sowing where only a trace of downy mildew was observed (Fig. 3). Downy mildew declined rapidly over this assessment period and was no longer evident by a September 8 assessment. No Septoria blight appeared at this site.

Location-specific results - Lake Grace. For Ascochyta blight at 80 days after sowing, there were significant effects of time of sowing $(P<0.001)$ and sowing density $(P<0.01)$ and a significant interaction between time of sowing with sowing density $(P<0.001)$ in relation to severity of Ascochyta blight. The early time of sowing had more severe Ascochyta blight $(P<0.05)$ than the mid and late times of sowing (Fig. 2). Disease was more severe $(P<0.05)$ at a sowing density of 100 plants $\mathrm{m}^{-2}$ compared to 50 or 25 plants $\mathrm{m}^{-2}$ (Fig. 2). Direct examination and plating Ascochyta blight lesions on leaves and stems onto potato dextrose agar as sampled at 80 days after the first time of sowing indicated that Didymella had excellent association (98\%) with lesions while Phoma had poor association (6\%) with these lesions (Table 1). There was no downy mildew or Septoria at this site.

Location-specific results - Merredin. For Ascochyta blight, by 80 days after sowing, the only significant effect was time of sowing $(P<0.001)$, where the early and mid times of sowing had more severe Ascochyta blight $(P<0.05)$ than the late time of sowing (Fig. 2). Disease levels were generally low and the early and mid times of sowing had more severe Ascochyta blight $(P<0.05)$ than the late time of sowing (Fig. 2). There were no effects of sowing density or differences in disease susceptibility between the varieties. By July 24 , again, the only significant effect was time of sowing $(P<0.001)$. The early and mid-time of sowing had more severe Ascochyta blight than the late time of sowing. For both the August 7 and 27 assessments, there were significant effects of time of sowing, variety, and sowing density $(a l l ~ P<0.001)$ and a significant interaction between time of sowing with variety $(P<0.001)$ and with sowing density $(P<0.05)$ for August 7 and $\mathrm{P}<0.001$ for August 27 in relation to severity of Ascochyta blight. The early time of sowing had more severe Ascochyta blight $(P<0.05)$ than the mid time of sowing, which in turn had more severe disease than the early time of sowing. Pennant had more severe Ascochyta blight $(P<0.05)$ than the other varieties. Ascochyta blight was more severe at a sowing density of 50 and 100 plants $\mathrm{m}^{-2}$ compared to 25 plants $\mathrm{m}^{-2}$. On August 22 there was a three-way interaction between time of sowing, variety and sowing density There was also a significant $(P<0.05)$ interaction of time of sowing with variety, and time of sowing with sowing density. For the September 5 assessment, there were significant effects of time of sowing, variety, and sowing density (all $P<0.001)$ and a significant interaction between time of sowing with variety $(P<0.001)$ and 
with sowing density $(P<0.001)$ in relation to severity of Ascochyta blight. The early time of sowing had more severe Ascochyta blight $(P<0.05)$ than the mid time of sowing, which in turn had more severe disease $(P<0.05)$ than the early time of sowing. Pennant had more severe Ascochyta blight $(P<0.05)$ than the other varieties. Ascochyta blight was more severe $(P<0.05)$ at 100 compared to 50 plants $\mathrm{m}^{-2}$, which in turn had more severe disease $(P<0.05)$ than at 25 plants $\mathrm{m}^{-2}$. Direct examination and plating Ascochyta blight lesions on leaves and stems onto potato dextrose agar as sampled 80 days after the first time of sowing showed that Didymella had good association (77\%) with lesions, while Phoma had much lower association (12\%) (Table 1).

For downy mildew, at August 27, there were significant effects of time of sowing, variety, and sowing density, and a significant interaction between time of sowing with variety and with sowing density (all $\mathrm{P}<0.001)$ in relation to its severity. There was more severe downy mildew $(P<0.05)$ in the late time of sowing compared to the mid time of sowing which in turn had more severe disease than the early time of sowing (Fig. 3). Alma had more severe downy mildew compared with Dundale, which in turn had more than Pennant, that in turn had more than Wirrega (all $P<0.05$ ); these effects particularly evident at the late time of sowing (Fig. 3). Downy mildew was more severe $(\mathrm{P}<0.05)$ at 50 and 100 plants $\mathrm{m}^{-2}$ seeding rate compared to 25 plants $\mathrm{m}^{-2}$, particularly for the late time of sowing (Fig. 3). Across all times of sowing there was a very rapid decrease in the severity of downy mildew as the season progressed, from a $\% \mathrm{DI}$ of 55 to 2,15 to 0.1 and 0.5 to $<0.01$, respectively, for the third, second and first times of sowing. There was no Septoria blight at this site.

Location-specific results - Moora. For Ascochyta blight, by 80 days after sowing, there were significant effects of time of sowing $(P<0.001)$, and a significant interaction between time of sowing with variety $(P<0.05)$ in relation to severity of Ascochyta blight. The early time of sowing had more severe Ascochyta blight $(P<0.05)$ than the mid and late times of sowing (Fig. 2). There were no effects of variety or sowing density. By August 15, there were significant effects of time of sowing $(P<0.001)$, and a significant interaction between time of sowing with variety $(P<0.05)$ in relation to severity of Ascochyta blight. The early time of sowing had 6 -fold more severe $(P<0.05)$ Ascochyta blight compared with the mid and late times of sowing. By September 4 and at September 18 , the only significant effect was from time of sowing $(P<0.001)$ in relation to severity of Ascochyta blight. At both times, the early time of sowing showed more severe Ascochyta blight $(P<0.05)$ compared with the mid and late times of sowing. Direct examination and plating Ascochyta blight lesions on leaves and stems onto potato dextrose agar as sampled at 80 days after the first time of sowing indicated that Didymella had excellent association (93\%) with lesions while Phoma had poor association (12\%) with these lesions (Table 1).

For downy mildew assessments across the period August 15 to September 4 and 18, there was a rapid decrease in severity, being most severe $(P<0.05)$ for the late time of sowing at both August 15 and September 4 but not at September 
18 assessments (Fig. 3). By August 15, there was also a significant $(P<0.001)$ interaction between variety and sowing density, where most severe disease on Alma was at sowing densities 50 and then 25 plants $\mathrm{m}^{-2}$, on Dundale at sowing densities 50 then 100 plants $\mathrm{m}^{-2}$, on Pennant at sowing densities 100 then 50 plants $\mathrm{m}^{-2}$, and on Wirrega at sowing densities 25 then 100 plants $\mathrm{m}^{-2}$ (Fig. 3). There was no Septoria blight at this site.

\section{Discussion}

These studies, undertaken across five field locations in Western Australia in a single year (1989), highlight the relative changes in disease severity and subsequent field pea yield from up to four foliar pathogens associated with the field pea foliar disease complex (viz. genera Didymella, Phoma, Peronospora, Septoria). There were contrasting and locationspecific effects from delaying sowing of field pea, where it reduced severity of Ascochyta blight (all five locations) and Septoria blight (1 location), increased severity of downy mildew (4 locations); but, had no effect on seed yield. In relation to Ascochyta blight severity at 80 days after sowing, at all locations the early time of sowing had more severe Ascochyta blight than the mid and late times of sowing. Where seasonal conditions allow, delayed sowing is widely recommended and practiced across southern Australia (Salam et al. 2011c,d; Khan et al. 2013). However, an overriding challenge with utilizing a delayed time of sowing approach, was that while it reduced Ascochyta blight and Septoria blight, the end of season water stress for later sowings precluded any yield advantage from reduced Ascochyta and Septoria blights. That grain yield was highest in the current study for the early time of sowing at three locations highlights these seasonal challenges with delaying sowing, challenges as noted earlier by Salam et al. $(2011 \mathrm{c}, \mathrm{e})$.

Plant density effects were also often location-specific. For example, at four locations, increasing sowing density significantly increased Ascochyta blight (4 locations) and downy mildew (1 location). Despite this increase in Ascochyta blight and downy mildew, there was increased seed yield at four locations, irrespective of sowing date for all these locations and irrespective of variety for three of these locations. Towards offsetting the end of season water deficit, especially where delayed sowing has been employed as the major Ascochyta blight management strategy, there remains further scope to better exploit this particular cultural management option. The precise reasons for the variations in the severity of the different diseases in the current study were not determined, but many factors are known to influence their epidemic development. For example, for $D$. pinodes infection and development in the field, plant height, growth habit, canopy morphology, lodging and precocity, are all known to effect the microclimate in the canopy and conidia splash dispersal (Schoeny et al. 2007, 2008; Le May et al. 2009a,b; Fernández-Aparicio et al. 2010). In addition, there will be significant 
interactions between the different pathogens as has been shown for those within Ascochyta blight complex, not only in terms of the consequent overall severity of disease, but the differential disease severities across the different plant components (e.g., leaf, stem, epicotyl, root) (Tran et al. 2015, 2016).

There has been a failure to develop varieties with effective host resistance to Ascochyta blight, and reasons for this are many and varied. First, as demonstrated in both current and earlier studies (e.g., Tran et al. 2014a), the relative proportions of component pathogens of the Ascochyta blight complex fluctuate widely across time and geographic locations. This is particularly problematic for field screening and selection for varietal resistance, where resistance(s) are unintentionally identified to the particular pathogen complex components prevailing at each particular field screening location. It is also problematic for subsequent commercialisation of any such resistance(s) as their deployment shifts the composition of different pathogens within the complex towards other pathogens in the Ascochyta blight complex less restricted by that particular resistance. The challenges in developing varietal resistance against multiple pathogens of the Ascochyta blight complex have been previously reported where individual defence proteins down-regulated against $P$. koolunga (Tran et al. 2018) are in fact up-regulated against D. pinodes (Prioul-Gervais et al 2011; Fondevilla et al. 2001). Second, that the expressions of host resistance across field pea genotypes are generally different on stem versus leaf (Tran et al. 2015), with stem and leaf resistances generally being inherited independently. For example, the two non-allelic stem resistance genes, $R m p 1$ and $R m p 2$, differ from the two leaf resistance genes, Rmp3 and Rmp4 (Clulow et al. 1991). Further, some screening tests under controlled conditions remain focused solely on either stems or leaves rather than including both plant components. Third, that no truly effective sources of resistance against $D$. pinodes have been commercialized. However, Tran et al. (2015) showed that it is possible to achieve improved host resistance if germplasm is screened against each individual pathogen of the Ascochyta blight complex and separately on both stems and on leaves. Such an approach potentially offers improved outcomes for field pea breeders and producers, provided that such resistances could subsequently be pyramided together. However, despite these three major challenges to the search for improved host resistance, it is encouraging that some identified 'less susceptible' pea genotypes, both in the current study and subsequently, likely facilitate a modest basis for combining with a range of cultural and/or fungicidal management options into Integrated Disease Management packages against Ascochyta blight.

While yield losses due to Ascochyta blight can be large, these also vary depending upon environmental conditions, location and cropping practices, as highlighted in the current study. Similar variations are also reported in other studies, such as for France, where only in 7 years out of 10 does Ascochyta blight reduce yield by 20\% (Maufras 1997); for Canada, where average yield losses approximate $10 \%$ but can exceed $50 \%$ in some situations (Xue et al. 1997); and in Australia, 
where overall annual average yield losses approximating 10\% (Bretag et al. 2006) hide the extensive variation in losses across different locations. In all three countries, yield losses can range from relatively low to as high as $30-75 \%$, with losses dependent upon the particular season (Xue et al., 1997; Roger et al. 1999; Kaiser et al. 2000; Bretag and Ramsey 2001; McDonald and Peck 2009). However, of even greater challenge, is the wider foliar disease complex than just Ascochyta blight. For example, in the current study, variety Alma showed less severe Ascochyta (1 location), downy mildew (1 location) and Septoria blight (1 location) compared with varieties Dundale, Wirrega and Pennant. However, there was no indication that overall the greenish-brown seeded 'Dun' types Alma and Dundale were overall more resistant thant the white seeded Wirrega and Pennant varieties. Hence, a broader approach that includes searching for varietal resistance(s) to prevailing foliar diseases outside the Ascochyta blight complex should be beneficial in the long term. However, in the interim until improved host resistance against at least the most damaging pathogens within the Ascochyta blight complex becomes available, there is clearly a need to better exploit a wider range of cultural management options, including those in the current study.

The percentage of isolations of individual Ascochyta blight pathogens varied greatly in the current study, yielding Didymella from $25-93 \%$ and Phoma from 6-23\% across the five field locations. This fluctuating nature of individual pathogen types and proportions within the Ascochyta blight complex, along with variation in occurrence of Peronospora and Septoria, highlights the challenges to understand and manage the complexities of co-occurring different foliar pathogens of field pea. Even just the different individual pathogens in the Ascochyta blight complex can 'disappear' or 'appear'. For example, while A. pisi was reported in Western Australia in 1912, 1927 and 1968, it was not found either in the current study or in the comprehensive survey of Ascochyta blight pathogens undertaken by Tran et al. (2014a). Further, B. exigua var. exigua was recorded at three locations in Western Australia in 1989 (Tran et al. 2014a), but not subsequently; and P. herbarum and P. glomerata were only identified in 2010 and 2012 (Tran et al. 2014a), respectively. That one or more species of the complex can 'disappear' or 'reappear' is well documented (e.g., Li et al. 2011, 2012; Tran et al. 2014a) and highlights the highly fluctuating nature of the Ascochyta blight complex, certainly for Western Australia. Further examples include a survey across South Australia in 1976 where $A$. pisi was the most prevalent pathogen causing leaf and pod spot on field pea (Ali et al. 1978, 1993), and in Victoria, Australia, where Bretag et al. (1995) reported 95\% of isolates from $>435$ seed lots tested were $D$. pinodes, only $4 \%$ were $P$. pinodella and $1 \% A$. pisi. Similarly, in France, $A$. pisi was found at high incidence in the southern regions, but $D$. pinodes remained the dominant pathogen. In France, Le May et al. (2009b) found both antagonism and synergism between the different pathogens of the pea Ascochyta blight complex. In Canada 85\% of seed lots infected with one or more pea Ascochyta blight pathogens were infected by A. pisi 
(Hwang et al. 1991; Tivoli and Banniza 2007). In Spain, a pea Ascochyta blight epidemic in 2005-2006 was primarily attributed to A. pisi (Kaiser et al. 2008), despite it being widely considered the least damaging among the pathogens in the pea Ascochyta blight complex (Wallen 1965). In contrast, in India, only 1 out of 40 Ascochyta blight isolates recovered across pea growing areas of Himachal Pradesh was A. pisi (Padder et al. 2012).

Dominance, or otherwise, of any foliar pathogen in a region or location can be strongly influenced by crop management decisions. For example, development and deployment of even low levels of host resistance against particular pathogens within the foliar disease complex likely radically shifts the composition of the population towards pathogen species that are less sensitive to particular host resistance(s) (Tran et al. 2014a). An example is for Canada, where introduction of resistance to A. pisi in the mid-1960's resulted in D. pinodes becoming the dominant species on field pea seed (Tivoli and Banniza, 2007). The same can situation can occur with fungicides, as the efficacy of fungicides currently applied to manage pea Ascochyta blight in Australia (e.g., Bretag et al. 2006; McMurray et al. 2011) or elsewhere (e.g., Chongo et al. 2003; Maude et al. 1969, 1970; Warkentin et al. 1996) are not equally effective across the spectrum of pathogens within the Ascochyta blight complex. In fact, in three other field trials in Western Australia conducted in the same year (1989) as the current studies, diverse fungicide seed and soil treatments for Ascochyta blight management were also found to be location-specific, effective at only at one of the three locations (MJ Barbetti et al., unpubl. data). Hence, current management practices involving host resistance and/or fungicides actually ensure that the pea foliar disease complex, particularly the Ascochyta blight component, remains severe despite advances in management practices, especially plant breeding programs. These examples highlight the fluidity of composition of the Ascochyta blight complex across time, geographic location and cropping practices, variability that continues to impede improved disease management in relation to deployment of effective host resistance and/or fungicidal management measures. Tran et al. (2014a) highlighted how failure to understand the true nature and modus operandi of the different pathogens within the pea Ascochyta blight complex impedes their management, despite its variable nature having been long-established.

Historically, there has been a strong focus on the above ground component of the Ascochyta blight complex, compared with much less focus on the soilborne component of this pathogen complex. Even when reported on roots, D. pinodes and P. pinodella have frequently been noted simply as 'non virulent pathogens' or as pathogens 'occasionally isolated from roots' (e.g., Tu 1986, 1987, 1992; Persson et al. 1997). Yet, D. pinodes, P. pinodella and P. koolunga not only survive as mycelium on infected pea trash, but also as sclerotia and/or chlamydospores in the soil. Hence, it is not surprising that root disease of field peas from D. pinodes and P. pinodella occurs widely in fields previously cropped to peas (Bretag et al. 2006), that these pathogens readily attack roots and epicotyls (Bretag et al. 2001, 2006; Tran et al. 2016), and that 
there is strong correlation between the level of soilborne Ascochyta blight fungi and decline in field pea yield (Bretag et al. 2001). In the Netherlands, Oyarzun et al. (1993) reported D. pinodes and P. pinodella as prevalent root rot pathogens; while in Sweden and Denmark, Persson et al. (1997) found P. pinodella to be one of the most frequently isolated pathogens from pea roots. Significantly, Tran et al. (2016) found that combinations of the different Ascochyta blight pathogens synergistically caused the most severe disease on epicotyls, lateral and tap roots. Perhaps this is a consequence not only of all three pathogens naturally co-occurring together in soil (Davidson et al. 2011), but that soilborne pathogens readily 'cooperate' as a complex to increase disease severity on legumes (Barbetti et al. 1986; Foster et al. 2017). Clearly, the soilborne component of the Ascochyta blight complex needs more serious consideration as it magnifies the challenge in resolving disease management solely through host resistance and/or fungicidal strategies onlny targeting the foliar component of field pea. There is a need to seriously reconsider and further investigate cultural management options, including those in the current study, for their potential to be effective components towards improved management of the Ascochyta blight complex both above and below ground.

Modeling offers the best practical opportunity to both understand and resolve the complexities of managing Ascochyta blight complexes, both below and above ground, and the wider foliar disease complex. There are several pre-existing models for Ascochyta blight, especially from France and Australia, but these only specifically deal with the foliar disease component. These include those involving: radiation use and interception efficiency and photosynthetically active radiation, and/or canopy structure (e.g., Béasse et al. 2000; Le May et al. 2005, 2008); and primary inoculum assessment modes based on weather-dependent values such as temperature, humidity, leaf wetness, wind speed data (e.g., Schoeny et al. 2007; Salam et al. 2011a,b,c; Richard et al. 2013; Bénézit et al. 2017). However, despite such modeling approaches, modeling the different pathogen components of the Ascochyta blight complex, and/or the wider foliar disease complex, and/or aspects of the soilborne Ascochyta blight complex component, all remain as opportunities yet to be exploited. In particular, modeling offers unique opportunities to understand and define the Ascochyta blight complex, involving the same pathogen species that operate above and below ground. This is perhaps the most realistic way to better understand and fully exploit the opportunities for utilizing a more inclusive approach to manage the Ascochyta complex, one that accommodates the differences across the different pathogen species in terms of their epidemiology, responses to host resistance, fungicidal and cultural options, influences of different farming systems, and effects of environmental factors.

In conclusion, the current study highlights the complexities of changes in relative disease severities across four different pathogens (viz. genera Didymella, Phoma, Peronospora, Septoria) and subsequent field pea yield across different times of sowing, sowing densities and varieties, based on varieties and pathogen strains present in the farming system at the 
end of the 1980's. The contrasting effects from delaying sowing of field pea, where it reduced severity of Ascochyta blight and Septoria blight, but increased severity of downy mildew, and all this with no net yield advantage, were generally location-specific in the current study. Similarly, sowing density effects were also generally location-specific, where increased plant density increased yield despite increased Ascochyta blight and/or downy mildew at particular locations. Varietal differences in the current study were also location-specific and other field studies have shown location-specific responses to fungicide applications (MJ Barbetti et al., unpubl. data). Clearly, there is a need to better define and understand the role and influence of location-specific conditions on the makeup of foliar disease complexes, as this is fundamental towards enabling integrated and effective cultural, host resistance or fungicidal management. In the interim, while the search for the elusive but more effective host resistance continues, it is imperative that a wider array of cultural management approaches are further explored and exploited, such as focussing on crop sequence diversification, intercropping, manipulating time of sowing and stand density, and application of improved seed sanitation and residue/inoculum management practices.

\section{Acknowledgements}

The field trials were funded by the Department of Primary Industry and Development Western Australia. We thank DPIRD technical staff for help with running field trials at Avondale, East Beverley, Lake Grace, Merredin and Moora. Martin Barbetti benefited from a grant of the INP-Toulouse visiting senior scientist program under the umbrella of Pr Grégory DechampGuillaume (ENSAT), to visit and work with French colleagues on this data. The authors declare that they have no known competing financial interests or personal relationships that could have appeared to influence the work reported in this paper.

\section{Literature Cited}

Ali, S. M., Sharma, B. and Ambrose, M. J. 1993. Current status and future strategy in breeding pea to improve resistance to biotic and abiotic stresses. Euphytica 73:115-126.

Ali, S., Nitschke, L., Dube, A., Krause, M., and Cameron, B. 1978. Selection of pea lines for resistance to pathotypes of Ascochyta pinodes, A. pisi and Phoma medicaginis var. pinodella. Aust. J. Agric. Res. 29:841-849.

Barbetti, M. J., Khan, T. N. and Floyd, R. 1989. Diseases of peas. Western Australian Department of Agriculture, Farmnote No. 21/89. 
Barbetti, M. J., Wong, D .H., Sivasithamparam, K. and D'Antuono, M. F. 1986. Response of subterranean clover cultivars to root rot fungi. Ann. Appl.Biol. 109:259-267.

Béasse, C., Ney, B. and Tivoli, B. 2000. A simple model of pea (Pisum sativum) growth affected by Mycosphaerella pinodes. Plant Pathol. 49:187-200.

Bénézit, M., Biarnès, V. and Jeuffroy, M-H. 2017. Impact of climate and diseases on pea yields: what perspectives with climate change? Oilseeds and fats, Crops and Lipids, 24:D103.

Biddle A. J., 2001. Downy mildew. In 'Compendium of pea diseases and pests (2nd edn)'. (Eds JM Kraft, FL Pfleger) pp. 29-30. (APS Press: St Paul, USA).

Bretag, T. W., 1991. Epidemiology and control of Ascochyta blight of field peas. La Trobe University, Australia.

Bretag, T.W. and Ramsey, M. 2001. Foliar diseases caused by fungi. In: Kraft, J.M., Pfleger, F.L. (Eds.), Compendium of Pea Diseases and Pests. The American Phytopathology Society, St Paul, Minnesota, pp. 24-28.

Bretag T. W., Keane P. J. and Price, T. V. 2006. The epidemiology and control of Ascochyta blight in field peas: a review. Aust. J. Agric. Res. 57:883-902.

Bretag, T. W., Price, T. V. and Keane, P. J. 1995. Importance of seed-borne inoculum in the etiology of the Ascochyta blight complex of field peas (Pisum sativum L) grown in Victoria. Aust. J. Exp. Agr. 35:525-530.

Bretag, T. W., Smith, L. M. and Ward, D. J. 2001. Effect of soil-borne Ascochyta blight fungi on the grain yield of field peas. In Tenth Australian Agronomy Conference, Hobart, Tasmania, Australia, (Vol. 29)

Chongo, G., Buchwaldt, L., Gossen, B., Lafond, G., May, W., Johnson, E. and Hogg, T. 2003. Foliar fungicides to manage Ascochyta blight Ascochyta rabiei of chickpea in Canada. Can. J. Plant Pathol. 25:135-142.

Clulow, S. A., Matthews, P. and Lewis, B. G. 1991. Genetic analysis of resistance to Mycosphaerella pinodes in pea seedlings. Euphytica, 58, 183-189.

Davidson, J. A. and Kimber, R.B.E. 2007. Integrated disease management of Ascochyta blight in pulse crops. Eur. J. Plant Pathol. 119:99-110.

Davidson, J. A., Krysinska-Kaczmarek, M., Kimber, R. B. E. and Ramsey, M. D. 2004. Screening field pea germplasm for resistance to downy mildew (Peronospora viciae) and powdery mildew (Erysiphe pisi). Australas. Plant Pathol. $33: 413-417$.

Davidson, J. A. and Ramsey, M. D. 2000. Pea yield decline syndrome in South Australia: the role of diseases and the impact of agronomic practices. Aust. J.Agric. Res. 51:347-354. 
Davidson, J. A, Hartley, D, Priest, M, Herdina, M. K, McKay, A. and Scott E. S. 2009. A new species of Phoma causes ascochyta blight symptoms on field peas (Pisum sativum) in South Australia. Mycologia 101:120-8.

Davidson, J. A., Krysinska-Kaczmarek, M., Leonforte, A.L. and McMurray, L. S. 2011a. Resistance to downy mildew (Peronospora viciae) in Australian field pea germplasm (Pisum sativum). Australas. Plant Pathol. 40:575-582

Davidson, J. A., Krysinska-Kaczmarek, M., Wilmshurst, C. J., McKay, A., Herdina, M. K. and Scott, E. S. 2011 b. Distribution and survival of Ascochyta blight pathogens in field pea cropping soils of Australia. Plant Dis. 95:12171223.

Davidson, J. A., Krysinska-Kaczmarek, M., McKay, H. A. and Scott, E. S. 2012. Comparison of cultural growth and in planta quantification of Didymella pinodes, Phoma koolunga and Phoma medicaginis var. pinodella, causal agents of Ascochyta blight on field pea (Pisum sativum). Mycologia 104:93-101.

Fernández-Aparicio, M., Amri, M., Kharrat, M. and Rubiales, D., 2010. Intercropping reduces Mycosphaerella pinodes severity and delays upward progress on the pea plant. Crop Protect 29:744-750.

Fondevilla, S., Kuster, H., Krajinski, F., Cubero, J. I. and Rubiales, D. 2011. Identification of genes differentially expressed in a resistant reaction to Mycosphaerella pinodes in pea using microarray technology. BMC Genomics 12:28. doi: $10.1186 / 1471-2164-12-28$

Foster, K., You, M. P., Nietschke, B., Edwards, N. and Barbetti, M. J. 2017. Widespread decline of subterranean clover pastures across diverse climatic zones is driven by soilborne root disease pathogen complexes. Crop Past. Sci. 68:33-44

Gossen, B. D., Hwang, S. F., Conner, R. L. and Chang, K. F. 2011. Managing the Ascochyta blight complex on field pea in western Canada. Prairie Soils Crops J. 4:135-141.

Hagedorn, D. J. 1984. Compendium of pea diseases. St. Paul, Minnesota, USA: American Phytopathological Society.

Hwang, S. F., Lopetinsky, K. and Evans, I. R. 1991. Effects of seed infection by Ascochyta spp., fungicide seed treatment, and cultivar on yield parameters of field pea under field conditions. Can. Plant Dis. Surv. 71:169-172.

Kaiser, W. J., Ramsey, M. D., Makkouk, K. M., Bretag, T. W., Acikgoz, N., Kumar, J. and Nutter, F. W. 2000. Foliar diseases of cool season food legumes and their control. Curr Plant Sci Biot 34:437-455.

Kaiser, W., Viruega, J., Peever, T. and Trapero, A. 2008. First report of Ascochyta blight outbreak of pea caused by Ascochyta pisi in Spain. Plant Dis. 92:1365-1365. 
Khan, T. N., Timmerman-Vaughan, G., Rubiales, D., Warkentin, T., Siddique, K., Erskine, W. and Barbetti, M. J. 2013. Mycosphaerella pinodes and its management in field pea: challenges and opportunities. Field Crops Res. 148:6177.

Kraft, J. M. 2001. Foliar Diseases of Local or Minor Imortance In 'Compendium of pea diseases and pests (2nd edn)'. (Eds JM Kraft, FL Pfleger) p. 32. (APS Press: St Paul, USA).

Le May, C., Guibert, M., Leclerc, A., Andrivon, D. and Tivoli, B. 2012. A single, plastic population of Mycosphaerella pinodes causes Ascochyta blight on winter and spring peas (Pisum sativum) in France. Appl. Environ. Microbiol. 78:8431-8440.

Le May, C., Ney, B., Lemarchand, E., Schoeny, A. and Tivoli, B., 2009a. Effect of pea plant architecture on spatiotemporal epidemic development of Ascochyta blight (Mycosphaerella pinodes) in the field. Plant Pathol 58:332-343.

Le May, C., Potage, G., Andrivon, D., Tivoli, B. and Outreman, Y. 2009b. Plant disease complex: antagonism and synergism between pathogens of the Ascochyta blight complex on pea. J. Phytopathol. 157:715-721.

Le May, C., Schoeny, A., Tivoli, B. and Ney, B. 2005. Improvement and validation of a pea crop growth model to simulate the growth of cultivars infected with Ascochyta blight (Mycosphaerella pinodes). Eur. J. Plant Pathol. 112:1-12.

Li, Y. P., You, M. P., Finnegan, P. M., Khan, T. N., Lanoiselet, V., Eyres, N. and Barbetti, M. J. 2012. First report of black spot caused by Boerema exigua var. exigua on field pea in Australia. Plant Dis. 96:148.

Li, Y. P., You, M. P., Khan, T. N., Finnegan, P. M. and Barbetti, M. J. (2011). First report of Phoma herbarum on field pea (Pisum sativum) in Australia. Plant Dis. 95:1590-1590.

McDonald, G. K. and Peck, D. 2009. Effects of crop rotation, residue retention and sowing time on the incidence and survival of Ascochyta blight and its effect on grain yield of field peas (Pisum sativum L.). Field Crops Res. 111:1121.

Maude, R. and Kyle, A. M. 1970. Seed treatments with benomyl and other fungicides for the control of Ascochyta pisi on peas. Ann. Appl. Biol. 66:37-41.

Maude, R., Vizor, A. S. and Shuring, C. G. 1969. The control of fungal seed-borne diseases by means of a thiram seed soak. Ann. Appl. Biol. 64:245-257.

McKinney, H. H. 1923. Influence of soil temperature and moisture on infection of wheat seedlings by Helminthosporium sativum. J. Agric. Res. 26:195-218. 
McMurray, L., Davidson, J., Lines, M., Leonforte, A. and Salam, M. 2011. Combining management and breeding advances to improve field pea (Pisum sativum L.) grain yields under changing climatic conditions in south-eastern Australia. Euphytica 180:69-88.

Maufras, J. Y., 1997. L'anthracnose. In: ITCF, U. (Ed.), Maladies Du Pois Prote'agineux. ITCF, Paris, France, pp. 30-43. Moussart, A., Tivoli, B., Lemarchand, E., Deneufbourg, F., Roi, S. and Sicard, G. 1998. Role of seed infection by the Ascochyta blight pathogen of dried pea (Mycosphaerella pinodes) in seedling emergence, early disease development and transmission of the disease to aerial plant parts. Eur. J. Plant Pathol. 104:93-102.

Onfroy, C, Tivoli, B., Corbiere, R.. and Bouznad, Z. 1999. Cultural, molecular and pathogenic variability of Mycosphaerella pinodes and Phoma medicaginis var. pinodella isolates from dried pea (Pisum sativum) in France. Plant Pathol. 48:218-29.

Onfroy, C., Baranger, A. and Tivoli, B. 2007. Biotic factors affecting the expression of partial resistance in pea to Ascochyta blight in a detached stipule assay. Eur. J. Plant Pathol. 119:13-27.

Oyarzun, P., Gerlagh, M. and Hoogland, A. E. 1993. Pathogenic fungi involved in root-rot of peas in the Netherlands and their physiological specialization. Netherlands J. Plant Pathol. 99:23-33.

Padder, B., Kapoor, V., Kaushal, R. and Sharma, P. 2012. Identification and genetic diversity analysis of Ascochyta species associated with blight complex of pea in a northwestern hill state of India. Agric. Res. 1:325-337.

Persson, L., Bødker, L. and Larsson-Wikström, M. 1997. Prevalence and pathogenicity of foot and root rot pathogens of pea in southern Scandinavia. Plant Dis. 81:171-174.

Prioul-Gervais, S., Deniot, G., Receveur, E M., Frankewitz, A., Fourmann, M., Rameau, C., Pilet-Nayel, M-L. and Baranger, A. 2007. Candidate genes for quantitative resistance to Mycosphaerella pinodes in pea (Pisum sativum L.). Theor. Appl. Genet. 114:971-84.

Punithalingam, E. and Gibson, I. A. S. 1976. Phoma medicaginis var. pinodella. In. CMI Descriptions of Pathogenic Fungi and Bacteria No. 518. Kew, Surrey, UK: CAB International.

Punithalingam, E. and Holliday, P, 1972. Mycosphaerella pinodes. CMI Descriptions of pathogenic fungi and bacteria, 12.

Richard, B., Bussière, F., Langrume, C., Rouault, F., Jumel, S., Faivre, R. and Bernard Tivoli. 2013. Effect of pea canopy architecture on microclimate and consequences on Ascochyta blight infection under field conditions. Eur. J. Plant Pathol. 135:509-524. 
Roger, C., Tivoli, B. and Huber, L., 1999. Effects of temperature and moisture on disease and fruit body development of Mycosphaerella pinodes on pea (Pisum sativum). Plant Pathol 48:1-9.

Salam, M.U. and Galloway, J. 2005. "Blackspot Manager" for understanding blackspot of peas and Ascochyta blight management. Lupin and Pulse Updates, Agribusiness Crop Updates Conference. Department of Agriculture, Western Australia, Perth, Western Australia, pp. 67-69.

Salam, M. U., Galloway, J., MacLeod, W. J., Davidson, J. A., Seymour, M., Pritchard, I., Salam, K. P., Diggle, A. J. and Maling, T. 2011a.. G1 blackspot manager model predicts the maturity and release of ascospores in relation to Ascochyta blight on field pea. Australasian Plant Pathol. 40:621-631.

Salam, MU, MacLeod, W. J., Pritchard, I., Seymour, M., Davidson, J. A., Salam, K. P., Galloway, J., McMurray, L. S., Lindbeck, K. D.. Richardson, H. 2011b. G2 Blackspot Manager model to guide field pea sowing for southern Australia in relation to Ascochyta blight disease. Australas. Plant Pathol. 40:632-9.

Salam, M. U., MacLeod, W. J., Maling, T., Prichard, I., Seymour, M. and Barbetti, M. J. 2011c. A meta-analysis of severity and yield loss from Ascochyta blight on field pea in Western Australia. Australas. Plant Pathol. 40:591-600.

Salam, M. U., Galloway, J., Diggle, A. J., MacLeod, W. J. and Tim Maling. 2011d. Predicting regional-scale spread of ascospores of Didymella pinodes causing Ascochyta blight disease on field pea. Australas. Plant Pathol. 40:640647.

Salam, M.. U., MacLeod, W. J., Salam, K. P., Maling, T. and Barbetti, M. J. 2011e. Impact of climate change in relation to Ascochyta blight on field pea in Western Australia. Australas. Plant Pathol. 40: 397-406.

Schoeny, A., Menat, J., Darsonval, A., Rouault, F., Jumel, S. and Tivoli, B., 2008. Effect of pea canopy architecture on splash dispersal of Mycosphaerella pinodes conidia. Plant Pathol. 57:1073--1085.

Schoeny, A., Jumel, S., Rouault, Le May, C. and Tivoli, B. 2007. Assessment of airborne primary inoculum availability and modelling of disease onset of Ascochyta blight in field peas. Eur. J. Plant Pathol. 119:87-97.

Taylor, P. N., Lewis, B. G., Mathews, P. 1989. Pathotypes of Peronospora viciae in Britain. J. Phytopathol. 127:100-106.

Tivoli, B. and Banniza, S. 2007. Comparison of the epidemiology of Ascochyta blights on grain legumes. Eur. J. Plant Pathol. 119:59-76.

Tivoli, B. and Lemarchand, E. 1992. Fungal and bacterial foliar disease survey of combining pea in France in 1991. 1st European Conference on Grain Legumes. ITCF, Angers. France, pp. 363-364.

Tran, H. S., Li, Y. P., You, M. P., Khan, T. N., Pritchard, I, Barbetti, M. J. 2014a. Temporal and spatial changes in the pea black spot disease complex in Western Australia. Plant Dis. 98:790-6. 
Tran, H. S., Li, Y. P., You, M. P., Khan, T. N., Pritchard, I. and Barbetti, M. J. 2014b. Resistance in field pea (Pisum sativum) to the black spot disease complex in Western Australia. Eur. J. Plant Pathol. 140: 597-605.

Tran, H. S., You, M. P., Lanoiselet, V., Khan, T. N. and Barbetti, M. J. 2014c. First Report of Phoma glomerata associated with the Ascochyta blight complex on field pea (Pisum sativum) in Australia. Plant Dis. 98:427.

Tran, H. S., You, M. P., Khan, T. N. and Barbetti, M. J. 2015. Relative host resistance to black spot disease in field pea (Pisum sativum) is determined by individual pathogens. Plant Dis. 99:580-7.

Tran, H. S., You, M P., Khan, T. N. and Barbetti, M. J. 2016. Pea black spot disease complex on field pea: dissecting the roles of the different pathogens in causing epicotyl and root disease. Eur. J. Plant Pathol. 144:595-605

Tran, H. S., You, M. P. and Barbetti, M. J. 2018. Expression of defense related genes in stems and leaves of resistant and susceptible field pea (Pisum sativum) during infection by Phoma koolunga. Plant Pathol. 67:156-166.

Tu, J. C. 1986. Incidence and etiology of pea rots in southwestern Ontario. Can. Plant Dis. Surv. 66:35-36.

Tu, J. C. 1987. Integrated control of the pea root rot disease complex in Ontario. Plant Dis. 71:9-13.

Tu, J. C. 1992. Management of root rot diseases of peas, beans, and tomatoes. Can. J. Plant Pathol. 14:92-99.

Van der Gaag, D. J. an d Frinking, H. D. 1997. Survival characteristics of oospore populations of Peronospora viciae f. sp. pisi in soil. Plant Pathol. 46:978-988.

VSN International. 2019. Genstat for Windows 20th Edition. VSN International, Hemel Hempstead, UK. Web page: Genstat.co.uk

Wallen, V. 1965. Field evaluation and the importance of the Ascochyta complex on peas. Can. J. Plant Sci. 45:27-33.

Warkentin, T., Rashid, K. and Xue, A. 1996. Fungicidal control of Ascochyta blight of field pea. Can. J. Plant Sci. 76:6771.

Xue, A. G., Warkentin, T. D and, Kenaschuk, E. O. 1997. Effects of timings of inoculation with Mycosphaerella pinodes on yield and seed infection of field pea. Can J Plant Sci 77:685-689. 
Table 1. Relative percentage incidence of foliage isolations from field pea (Pisum sativum) yielding Didymella as compared with Phoma at 80 days after sowing at the five field trials at Avondale, East Beverely, Lake Grace, Merredin and Moora locations in Western Australia. A total of up to 80 leaves and 80 stems showing Ascochyta blight symptoms were sampled, examined directly under the microscope and then surface sterilized in $4 \% \mathrm{NaOCl}$ for 4 minutes and plated onto moist sterilized blotter paper in Petri dishes. Samples on moist blotter were examined at $48 \mathrm{~h}$ intervals under dissecting microscope for pathogen sporulation, slides made and examined under an Olympus compound microscope to determine if Didymella or Phoma spores were present on each lesion and relative percentage incidence of Didymella and Phoma associated with the disease symptoms calculated. In each case, identifications were confirmed by plating $1 \times 1 \mathrm{~mm}^{2}$ discs of leaf and stem diseased tissues onto potato dextrose agar containing 25 ppm aureomycin hydrochloride.

\begin{tabular}{lcc}
\hline Field location & \% isolations yielding Didymella & \% isolations yielding Phoma \\
\hline Avondale & 84 & 23 \\
East Beverley & 98 & 6 \\
Lake Grace & 25 & 15 \\
Merredin & 77 & 12 \\
Moora & 93 & 12 \\
\hline
\end{tabular}


Fig.1. Mean field pea seedling densities at 3 weeks post-germination made by counting the numbers of seedlings in 10 random quadrats each $0.5 \times 0.5 \mathrm{~m}$ per field plot (for plots originally sown at a density of 25,50 or 100 plants $\mathrm{m}^{-2}$ ) at Avondale, East Beverley, Merredin, and Moora field locations in Western Australia.
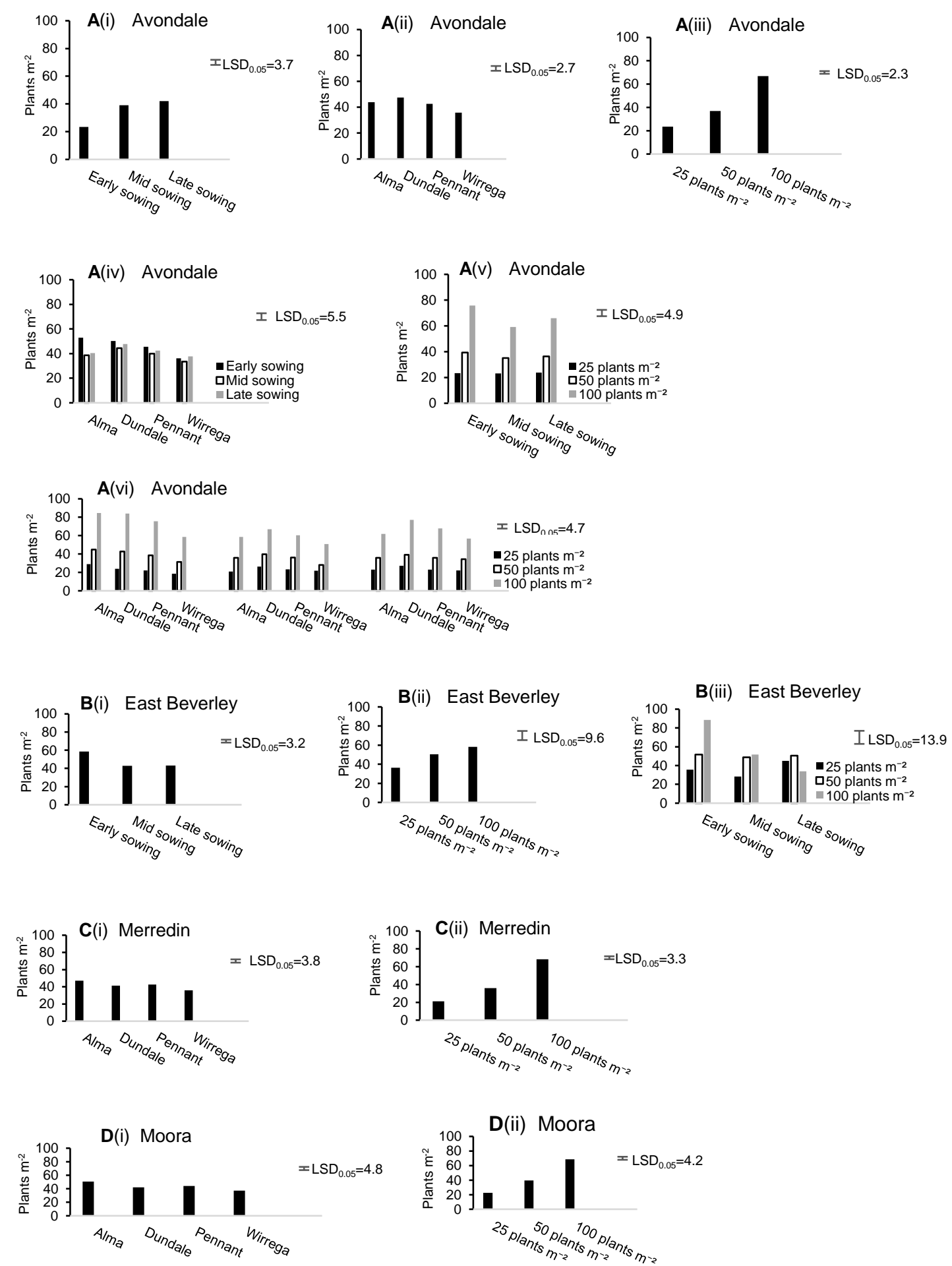
Fig. 2. Effect of sowing date (early, mid, late sowing), variety (Alma, Dundale, Pennant, Wirrega) and sowing density (25, 50 or 100 plants $\mathrm{m}^{-2)}$ ) on the severity \% Disease Indices for Ascochyta blight (Didymella, Phoma) at 80 days after sowing for each time of sowing for field pea grown at Avondale, East Beverley, Lake Grace, Merredin and Moora field locations in Western Australia.
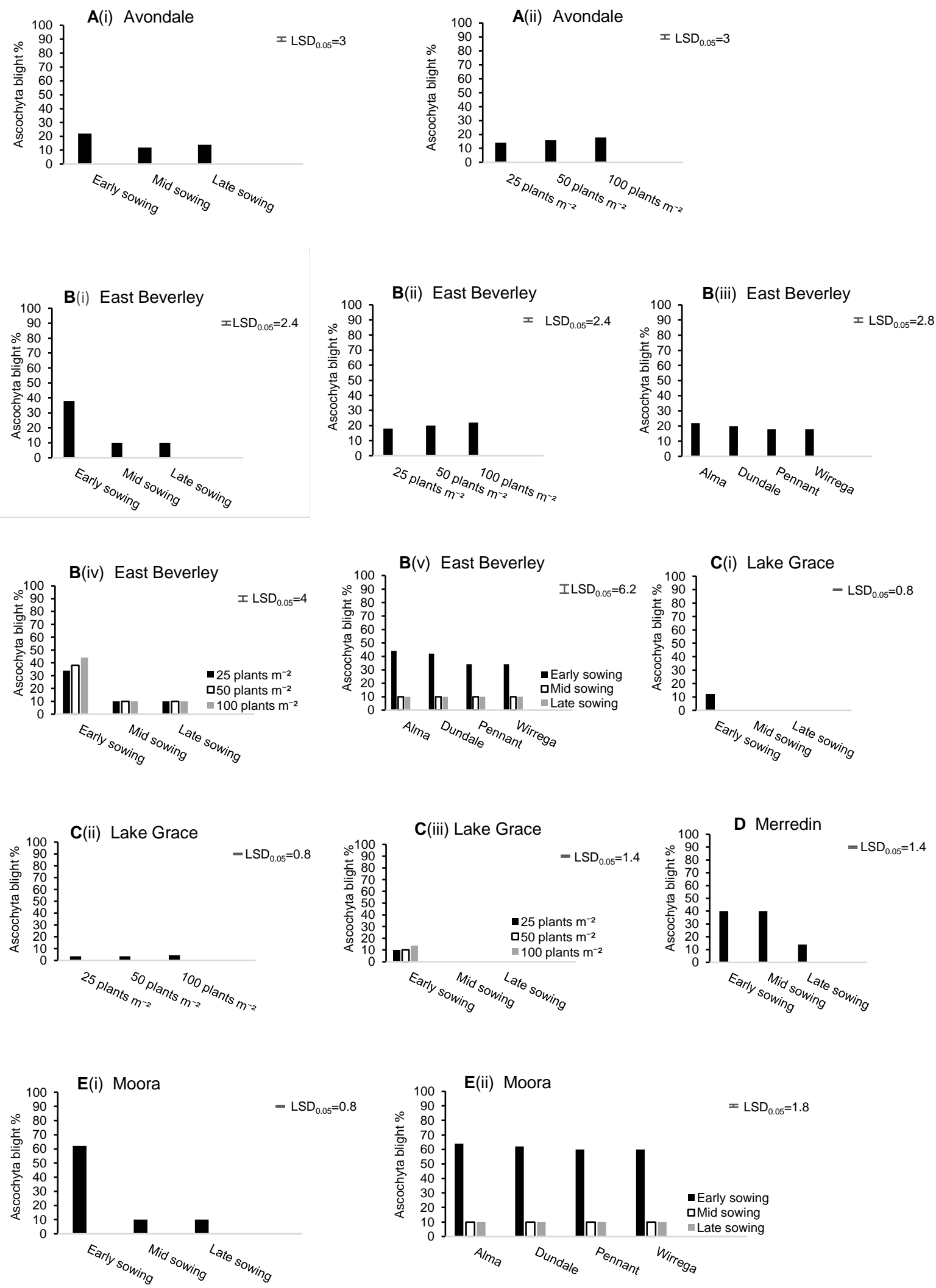
Fig. 3. Effect of sowing date (early, mid, late sowing), variety (Alma, Dundale, Pennant, Wirrega) and sowing density (25, 50 or 100 plants $\mathrm{m}^{-2}$ ) on the severity \% Disease Indices for downy mildew (Peronospora viciae) at various calendar dates for field pea grown at Avondale Research Station, East Beverley, Merredin, and Moora field locations in Western Australia.
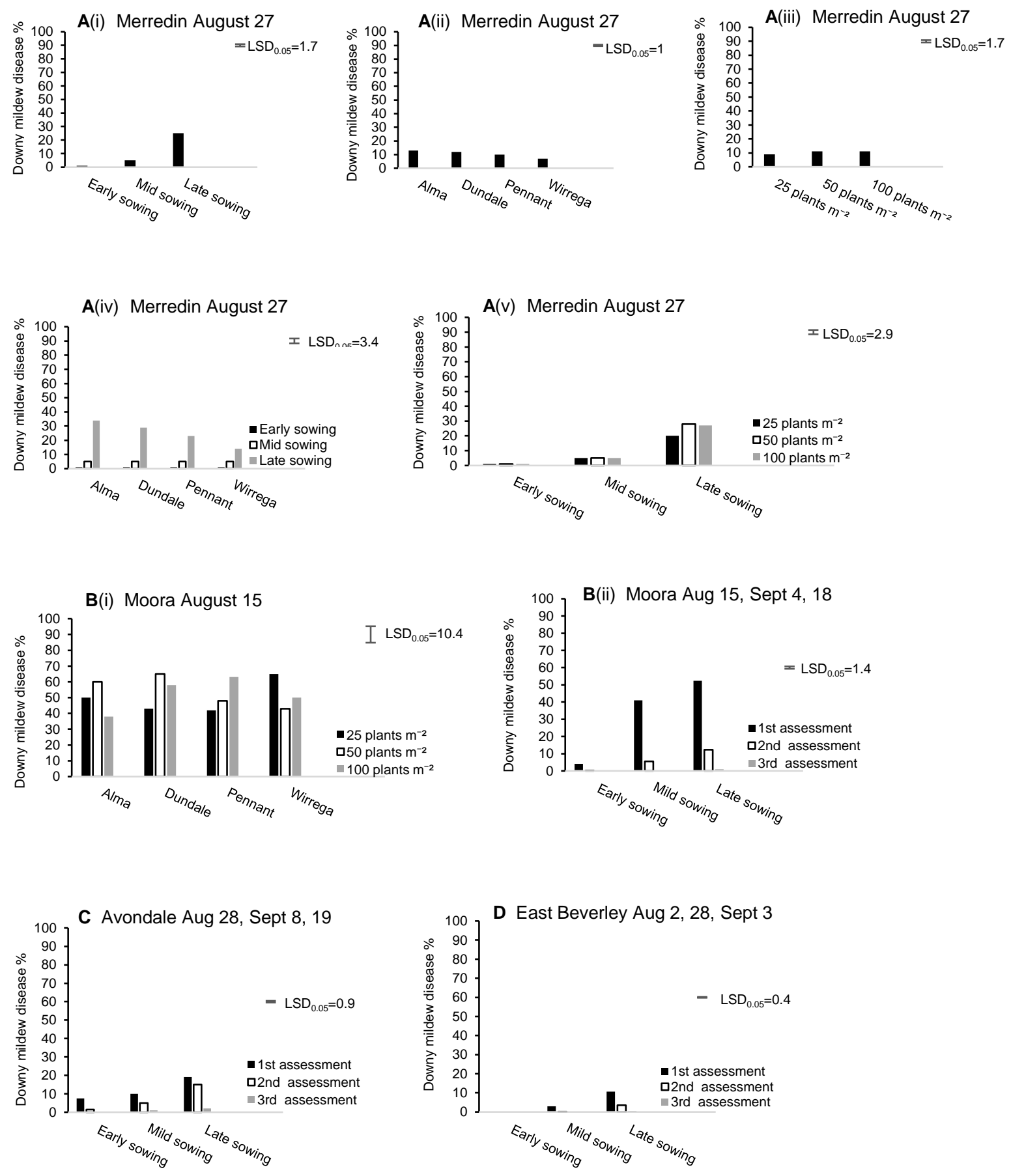
Fig. 4. Effect of sowing date (early, mid, late sowing), variety (Alma, Dundale, Pennant, Wirrega) and sowing density (25, 50 or 100 plants $\mathrm{m}^{-2}$ ) on the severity \% Disease Indices for Septoria blight (Septoria pisi) at various calendar dates for field pea grown at Avondale field location in Western Australia.
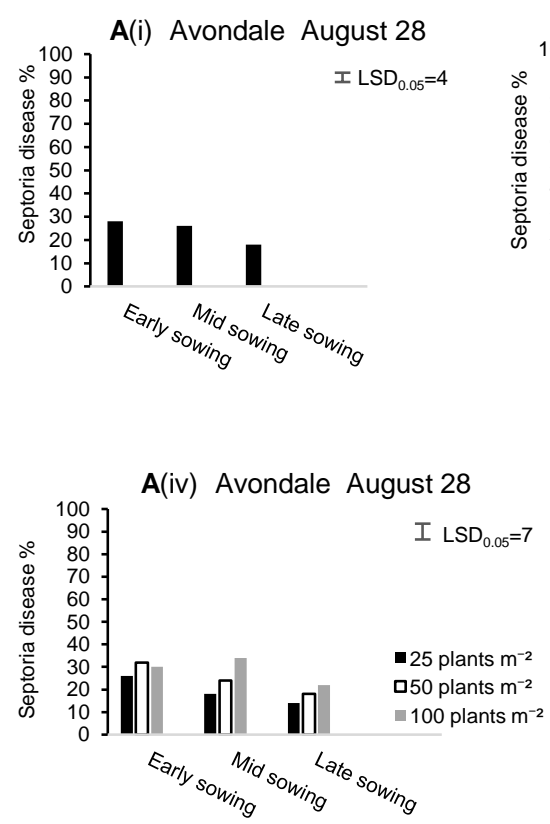

A(ii) Avondale August 28

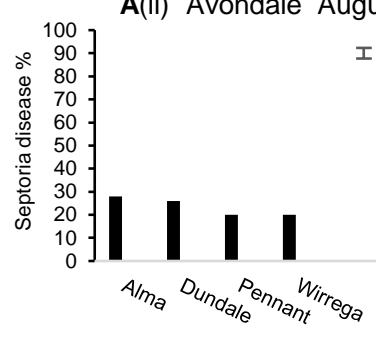

A(iii) Avondale August 28

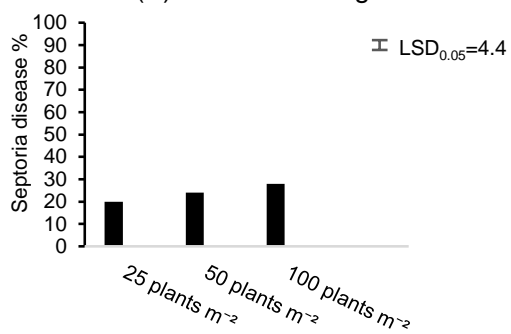

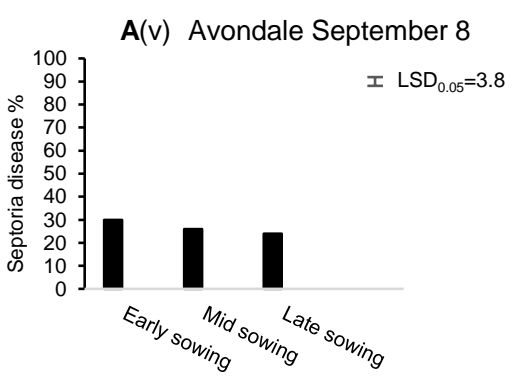
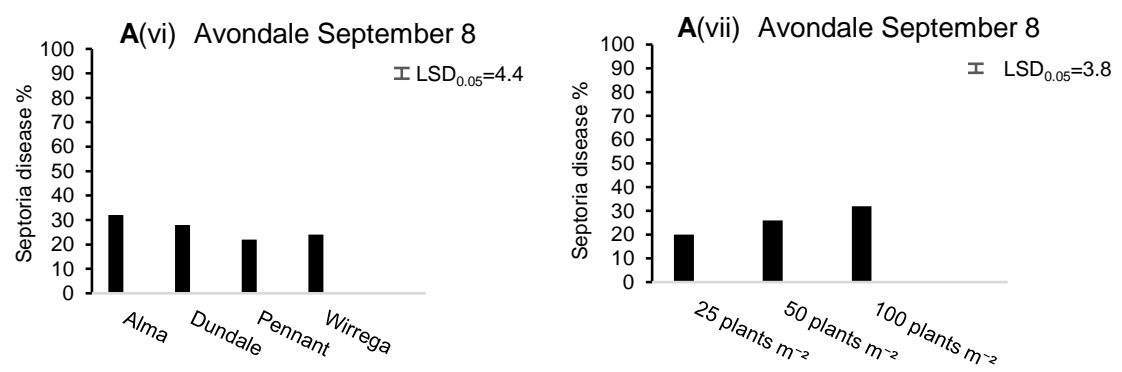
Fig. 5. Grain yield $\left(\mathrm{kg} \mathrm{ha}^{-1}\right)$ of field pea at Avondale, East Beverley, Merredin, and Moora field locations in Western Australia.
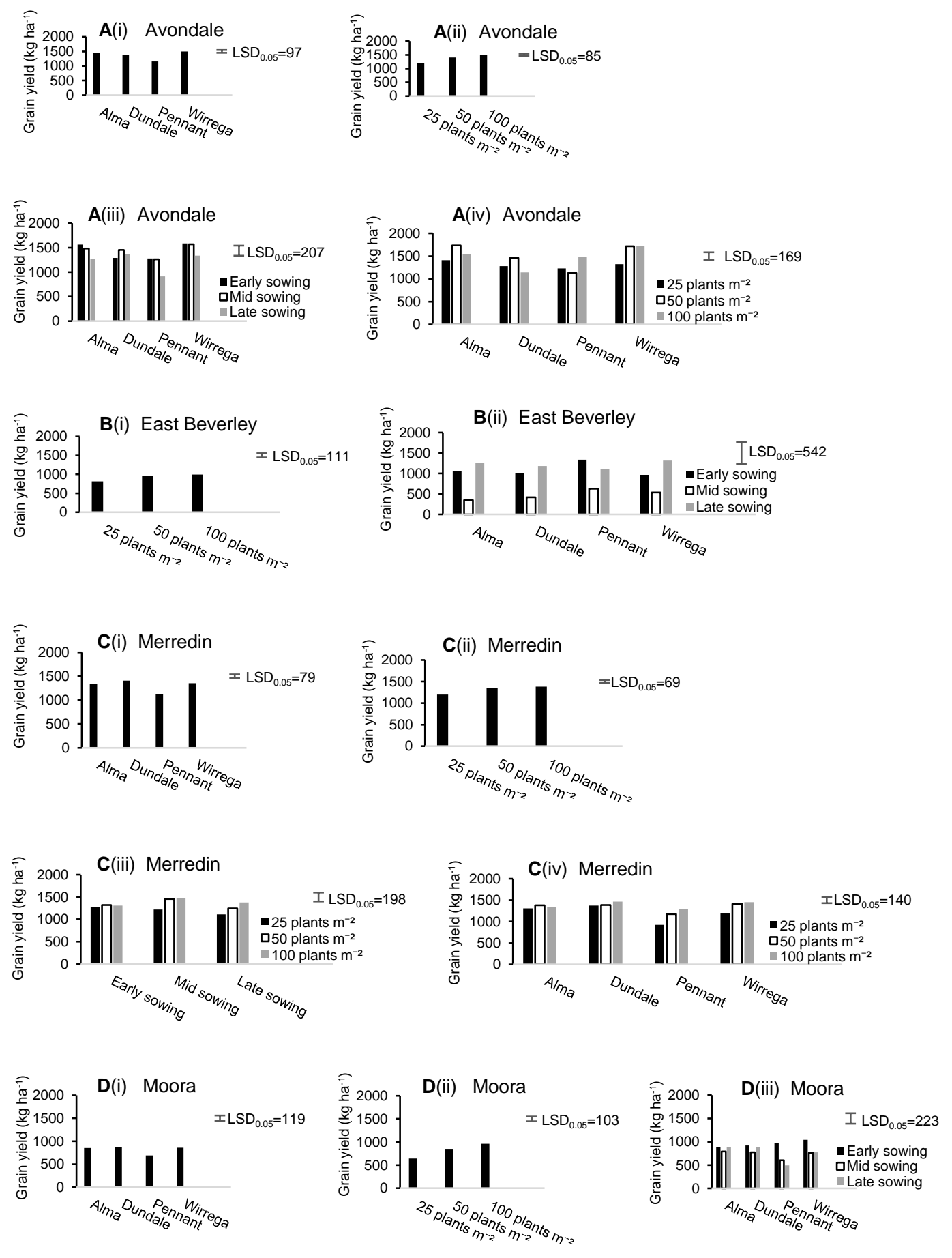